The Eclectic Paradigm: A New Deal?

\author{
Kurt Pedersen \\ Associate Professor \\ Head of Department \\ Department of International Business \\ The Aarhus School of Business \\ Fuglesangs allé 4 \\ DK-8210 Aarhus V \\ Denmark
}

Email: kur@asb.dk

\author{
Revision of article for \\ Journal of International Business and Economy
}

[Manuscript \#0239P] 


\title{
The Eclectic Paradigm: A New Deal?
}

\begin{abstract}
The 1970s was a decisive period in terms of theories of internationalization. Suffice it to mention the Uppsala model (1975, 1977), the transaction costs theory (1975) and the Porterian framework which was developed through the late 70s and ultimately presented in 1980. During the 1980s the development was spurred on with increasing emphasis on the process of internationalization. Resource-dependency and the resource-based view were added. 1976 saw the birth of the "eclectic paradigm" which was presented as, and remains, a theory of international production. The theory has now passed its silver anniversary, and this article seizes the opportunity to give the paradigm a routine check. Dunning's hits and misses are counted, and the conclusion suggests that the usual accusations of over-ambitiousness may be modified in that, in at least one sense, Dunning is under-ambitious. The eclectic theory might, from the outset, have been presented as a far more general theory of internationalization, thus anticipating some recent elaborations of the paradigm which have added to its relevance as a strategic tool for multinational corporations.
\end{abstract}




\section{THEORIES OF INTERNATIONALIZATION}

The internationalization of a firm is a complicated process rooted in the history of the firm and its administrative heritage as well as in its general strategic planning. It draws on a wide range of decisions over a variety of functions. Answers have to be found to questions concerning the selection of markets or segments, the (non-)adaptation of the product, and the choice of organization. The questions vary widely among industries (compare, e.g., the jet liner industry to the furniture industry), and among firms operating in the same industry.

These questions are addressed by theories of internationalization. Ultimately, the role of theory is to provide conditional statements of the "if - so" type, i.e., to suggest normative answers to questions formulated in suitable theoretical terms. Theories of internationalization inherently deal with questions of business development and strategy, two fields which are as much art as they are science, which shows in the theories of internationalization. These are not strong in terms of normative contents.

The evaluation of a theory often starts from generally accepted broad dimensions such as

- the transparency of the argument;

- the complexity of the theory;

- the consistency of the theory;

- the possibility of falsifying the theory; and

- the empirical content of the theory.

While the first three dimensions concern the internal part of theory, the latter two deal with 
the external relations. Even without satisfying (all of) the criteria, a theory may be quite useful. It may, e.g., use concepts that are fruitful in "practical life” and recognizable by managers, or it may be useful as a guide to practical decisions in the international firm.

Strandskov (1995) dealt with the - meta-theoretical - question of how to interpret and classify theories on internationalization. Introducing two alternative dimensions, Strandskov was able to group competing theories into four distinctly different categories.

The first category concerned the internationalization driver, i.e., the nature of the driving force behind the internationalization process. The distinction is a dichotomy between “internal” and “external” drivers. Internal drivers are found inside the company, e.g., in the form of a certain international mentality in the top management - a wish to "conquer the world”. External drivers may be opportunities spotted in foreign markets, e.g., an opportunity to serve new needs, or adverse developments in traditional marketplaces.

The second category involved the decision type, which covers the distinction between decisions taken through rational planning procedures and through organizational growth and development. The distinction is based on the observation that decisions are sometimes the output of a conscious and deliberate process and at other times spring from a piecemeal muddling-through process. Figure 1 presents Strandskov's framework and provides examples of theories that fit into the four boxes in the 2-by-2 matrix.

[INSERT TABLE 1 HERE] 
The transaction costs theory (Williamson 1975, 1985, Anderson and Gatignon 1986) provides an example of internationalization driven by company-internal forces on a foundation of rational planning. The theory has come under attack for its foundations as well as its onesided focus on costs and the fact that the unit of analysis is the transaction, not the firm, which may lead to some myopia.

The industrial economics perspective has been adopted by Michael Porter $(1980,1986)$, who, contrary to the micro-economic perspective, takes an even broader view than that of the firm. The key word is positioning, and the precondition for efficient positioning is knowledge about the environment. The approach is broad, and Porter (1991) clearly recognizes the necessity of its co-existence with other perspectives, in particular, those of the inter-organizational theories. Porter (1990) directly incorporates the innovation and competence-creating processes as essential parts of the positioning game. Contributions by Bartlett, Ghoshal and Nohria may be considered an expansion of the view (see Bartlett and Ghoshal 1989, Ghoshal and Nohria 1998). Like the micro-economic perspective, this one is based on rational decision processes, but the drivers for internationalization are predominantly external. George Yip (1992, 1995) takes this perspective to an extreme, arguing for globalization as a basic frame of mind for the international manager.

The opposite view to the Porter perspective is found in the Uppsala model and in other variations over the phase concept, i.e., the view that internationalization is not a planned or calculated process, but rather a set of activities that are developed from changing states of decision uncertainty faced by top management. According to this perspective, experiential learning is the key factor in internationalization. It is gathered piecemeal and gradually expands knowledge of different markets. The firm-internal learning process, in combination 
with commitment, determines the expansion from the home market to the fully fledged global multinational enterprise (Johanson and Wiedersheim-Paul (975, Johanson and Vahlne 1977). Later versions of the perspective deal with second stage internationalization based on MNEsubsidiaries (Hedlund 1986). Phase-models have been formulated by a number of scholars including Bilkey and Tesar (1977), Cavusgil (1980), and Czinkota (1982). Andersen (1993) has summarized much of the discussion of these theories.

The fourth group of theories, like the Scandinavian school, takes its starting point in external drivers and in an organic view of decisions. In this group, it is the relationships to other firms and organizations that are perceived as driving internationalization. One notable school of thought is the resource dependency approach (Pfeffer and Salancik 1978, Pfeffer 1987). In this perspective, internationalization takes place in dyadic relationships to partners with complementary resources. Access to scarce and valuable resources determines the path of internationalization. The struggle for resources leads to either strategies that change ownership, such as vertical integration, or strategies that imply joint ventures or other contractual relationships (see, e.g., Harrigan 1988). The network approach related to Håkansson (1987), Turnbull and Valla (1986) and others may be viewed as belonging to this group of theories.

From a philosophy of science perspective, internationalization theory has developed into a rather peculiar field. It is a mature industry with more stability than innovation (Casson 2000). It is also clear that, to a large extent, the theorists have remained in their trenches and little effort has been devoted to the integration of IB-thinking. This sharply contradicts the usual assumptions of a tendency towards "normal science” (Kuhn 1976) but is not quite unlike what 
we can find in other and even more mature sciences such as economics, where postKeynesian, neo-Keynesian and the dominating neoclassic positions still co-exist. In what follows, we turn our attention to John Dunning`s contribution.

\section{THE ECLECTIC PARADIGM}

The eclectic paradigm was first presented by John Dunning in a lecture related to the Nobel event in 1976. He followed up on this presentation in numerous articles and books, refining and expanding the original contribution. In a sense, the eclectic paradigm is much broader than the theories presented above; yet, in another sense, it is narrower.

It is broader than other theories on internationalization in the sense that it would be incorrect to place it squarely in one of the four boxes of figure 1 . Internationalization is spurred on by a combination of factors that are internal and external to the firm, and it leans vaguely, but not exclusively, on a "rational” approach to strategy. In the terminology of Michael Porter, it might be tempting to characterize the paradigm as "stuck in the middle". As is argued below, one should not be tempted.

At least in its early formulations, the paradigm is narrower in the sense that it addresses only one particular form of internationalization: international production in the form of FDI Foreign Direct Investment. The title of Dunning's main work is Explaining International Production (1988), and this clearly reflects his main business: the organization of global production in subsidiaries wholly owned by multinational firms. Dunning's early works followed a period with excessive interest in multinational enterprises (see, e.g., Aharoni 1966, 
Vernon 1966, 1971, Caves 1971). Political overtones dominated, but the search for a frame for understanding FDI and MNE was underway.

At the time, several mainly single-factor theories had been proposed to deal with the concept of FDI. These attempts have been surveyed by, e.g., Jürgen Stehn (1992) and J. P. Agarwal (1980), the latter offering four generic classes of explanations:

(1) Explanations relating to the function of the markets. This view includes hypotheses that FDIs are caused by differential rates of return between nations. The theme was expanded by hypotheses similar to financial portfolio models.

(2) Explanations based on market imperfections. The argument is that trade imperfections are barriers which may be circumvented by substituting trade with FDIs. The PLC hypothesis belongs under this umbrella (see Vernon 1966 for various models of oligopolistic behaviour; with respect to internalization theory see, e.g., Buckley and Casson 1976).

(3) Explanations related to firm behaviour, in particular investment behaviour. A number of variables were suggested to explain why FDIs were undertaken. The variables included cashflow, strength of currencies, the size of the MNE, expenditure on R\&D, etc.

(4) Explanations taking as their point of departure conditions in the host country. A broad range of political, economic and technological factors were suggested: political (in)stability, incentive systems, availability of essential factors of production, or the factor prices. In this group of theories, wages were particularly popular. 
The list is indicative and far from complete, leaving out, e.g., Marxist “explanations” of FDI, which are based on international exploitation. Understanding FDIs had become a highly disintegrated business and, if total disintegration was to be avoided, some general framework seemed necessary. This was what John Dunning offered (see Dunning 1979, 1988, 1993, 1995, 1997, 2000). Assuming that his eclectic framework is one of the best known of IB constructs, we provide only the shortest possible version below. The crux of the eclectic paradigm is the assumption that for an FDI to be undertaken, three necessary conditions have to be satisfied:

1. An MNE that invests abroad has to possess some sort of Ownership Advantage relative to local firms in the host country. O-advantages may relate to assets or transaction skills in the firm. Dunning lists numerous sources that may give rise to such advantages. In this respect, the Dunning framework has links to a whole number of theories of the firm, including network and resource dependency (relational O-advantages), the resource based theory and the value chain (Porter 1985). Dunning (1995) introduced alliance capitalism and thus the perspective that $\mathrm{O}$ advantages may be acquired or turned into shared assets. Below we deal with relationally based $\mathrm{O}$ advantages and their consequences for strategic planning.

2. The host country must have Location Advantages that favour FDIs. Again, there are numerous possible sources of L-advantages, some on the input-side (low factor prices, appropriate technology) and some on the output-side (market conditions). Institutional and structural arguments include the system of protection (trade barriers spur investment), infrastructure, etc. In his “Competitiveness of Nations”, Michael Porter (1990) formulated L- 
advantages in a specific industry-related framework.

3. Overseas operations have to possess Internalization Advantages. This implies that full control remains with the investing firm - a wholly owned subsidiary is preferable to other entry modes such as joint ventures, licensing or export. The arguments in favour of full control by an FDI include transaction costs, uncertainty and control of the distribution channel.

Several uses of the framework have been suggested, including the tracking of nations' development paths, i.e., the balance between in- and outgoing FDIs over the growth phases of an economy (see Dunning and Narula 1996, Strandskov and Pedersen 2000). As an IB theory, the crucial question relates to its applicability to the individual firm. Dunning (1988) argues that the paradigm has little predictive power for individual firms, while Dunning (1995) refers to the individual firm as the unit of analysis. The importance of this change will be elaborated on below.

Eclectic literally means 'taken from various sources' and a look at the FDI theories preceding OLI suffices to illustrate the eclectic nature of the framework. O advantages are borrowed from firm-related theories, L advantages from host-country related theories, and I advantages from theories on market imperfection.

The paradigm has been criticized for its broad and loose structure. One issue has been whether an approach which lumps evidence for $\mathrm{O}, \mathrm{L}$ and I-advantages can be operational. O, L and I represent necessary, not sufficient conditions for FDI. How many competencies a 
firm had to possess in order for O to be just “necessary” was unclear, however, as was the level of significance required for I-advantages to warrant an FDI.

Further criticism is directed toward the three kinds of advantages: are they independent and are they necessary? Rugman (1981) finds that, from an epistemological point of view, the border between O- and I-advantages is severely blurred. Casson (1987) argues that market failure in intermediate product markets is a necessary as well as sufficient condition for the existence of MNEs. Dunning (1988) is unable to entirely refute the argumentation and ends up agreeing in part with Rugman that O- and I-advantages have a tendency to become inseparable.

Later Itaki (1991) took up the point and, after a penetrating and logical tour-de-force, concluded that O-advantages are redundant in the sense that they can logically be classified as internationalization advantages that have (been) developed over time.

The eclectic paradigm has been revised and adjusted over time. It may, not unreasonably, be seen as a response to the heated debate on MNEs in the 1960s and 1970s. The debate cooled off, however, and IB increasingly turned towards alternative modes of internationalization. The 1980s and 1990s witnessed an increasing interest in strategic alliances, networking and joint ventures. Dunning (1995) turns attention towards alliance capitalism and more or less extends the whole framework to cooperative ventures of all sorts. The answer is to add a number of new O-advantages relating to the ability to build and sustain vertical and horizontal networks. In this way, advantages are claimed to be valid for groups of cooperating firms as well as for the individual MNE. Thus the resource dependency approach has been promoted, and the focus been widened to include the $\mathrm{O}$ advantages of foreign companies. 
In the meantime, Dunning (1993) had redefined the subject matter of the eclectic theory. Up to 1988, it dealt with international production exclusively, but now the theory was extended to cover all value creating activities. This is a severe break with former formulations of the paradigm which, in combination with the relational $\mathrm{O}$ advantages, heralds a new and broader theory of internationalization.

The positive side of the change is that the eclectic paradigm adds generality when other entry modes than FDI are taken into consideration. The downside is that OLI is assumed to explain just about anything by merely adding an extended set of variables. It seems reasonable to pose the question whether it explains all - or nothing. The following section draws inspiration from a footnote in Dunning (1988), which will be elaborated into a more general internationalization theory.

\section{ECLECTIC INTERNATIONALIZATION}

Initially the eclectic paradigm was formulated and used as a theory of FDI; in the present section, we deal first and foremost with this early phase. The exclusive focus was unnecessarily narrow and may easily be extended into a general theory of internationalization. Indeed, it had the potential of becoming a serious alternative to the ones presented in the above section on 'Theories of Internationalization'. Dunning (1988) provided a hint that might have been exploited in a very useful way. Table 2 is from chapter 2 of that work. 
[INSERT TABLE 2 HERE]

The table features three different modes of serving a foreign market. It may be done by way of direct international investment in production by establishing a subsidiary; it may be done as export by some distribution channel; or it may be effectuated by contractual agreements such as licensing, co-production or contractual joint ventures, i.e., arrangements which require some level of close cooperation between two or more parties. Each of the three modes is characterized by its specific "profile of advantages”. Dunning's work concentrates on direct investments and elaborates on cases which include the three kinds of advantages. In the absence of location advantages, Dunning suggests that trade substitutes direct investment. Curiously, however, he accepts the presence of internalization advantages in this case, meaning that there is some advantage to keeping control of the distribution channel. The only possible interpretation is that Dunning thinks of export by means of a sales subsidiary in the importing country. Contractual resource transfer by licencing, franchising or other sorts of bilateral agreements is assumed to take place in cases where there are neither I advantages nor L advantages. It looks a bit like a blunder: why transfer production or other knowledge to a country devoid of L advantages?

An alternative approach is offered here. The strikingly true observation is that, whatever the mode of entry, or market operation form, the firm must possess Ownership advantages. Without any $\mathrm{O}$ advantage, the firm would not be in a state to operate at all in a (foreign) market. For general classification purposes, it is redundant in the OLI-framework. In table 3, 
the LI-framework is set out to introduce a general theory of internationalization; $+\mathrm{I}$ and $+\mathrm{L}$ indicate the existence of the two kinds of advantages, while -I and -L represent their absence.

\section{[INSERT TABLE 3 HERE]}

In case (1), foreign markets are served from the home base because there are no advantages attached to overseas production or to internalization of operations. Case (4) is the traditional case for foreign direct investments. Case (2) is characterized by the absence of location advantages but the presence of some advantage(s) of keeping control. The case implies that downstream activities are controlled as far as possible towards the end-users. This may be obtained through a sales subsidiary, which in the (1988)-terminology is not an FDI, or possibly by the firm's own sales force operating in the foreign market, e.g,. in cases of industrial marketing.

Case (3) combines location advantages and internalization disadvantages. Whatever the kind of contract, there are good reasons to produce locally, but no particular reason for the foreign firm to keep direct control of the processes. The case covers a vast area of different forms of cooperation, as witnessed by the overwhelming literature on franchising, licensing, jointventures etc. For our purposes, the versatility of the cases is unimportant, unlike the common feature that internationalization is founded upon a contract (Williamson 1985).

In the real world of business, the type of contract is determined predominantly by characteristics of the two parties, i.e., their Ownership advantages. Dividing O-advantages roughly into upstream (R\&D, production) and downstream (service, marketing and sales) 
ones, we may scrutinize the four cases of strong or weak upstream, or strong or weak downstream, advantages.

Global leaders that are strong in upstream as well as downstream $\mathrm{O}$ advantages may enter strategic alliances, which is what we see in the global automotive industry. A company which is strong only in upstream $\mathrm{O}$ advantages may embark on a strategy of international licensing. This has been the case in the oligopolistic market for marine diesel engines in the better part of the $20^{\text {th }}$ century. A company which is strong in downstream $\mathrm{O}$ advantages might choose an international franchising strategy, building a comprehensive system of implementing, monitoring and controlling the delivery system. The cases are summarized in table 4.

\section{[INSERT TABLE 4 HERE]}

Obviously the table is simplified. In order to come to grips with the real business world, the $\mathrm{O}$ advantages, competencies, or resources should be mapped carefully and their interdependencies revealed in order to determine the competitiveness of the firm. For general purposes, however, the table suffices as an overall description of patterns of internationalization.

\section{A NEW DEAL}

While in earlier formulations of the eclectic paradigm, O advantages possessed by the investing MNE were a necessary condition for the internationalization of production activities, the contributions of the mid-nineties changed the perspective considerably. First, "production” was substituted with "value creating activities" in order to allow the deployment 
of upstream as well as downstream resources across borders. This was a significant step towards the creation of a true theory of internationalization. Second, Dunning's seminal work from 1995 recognized the increasing role of networks and alliances in international business. The concept of alliance capitalism was coined, and a driving force of internationalization was spotted: the acquisition, or sharing, of $\mathrm{O}$ advantages located in foreign firms. While ownership advantages have conventionally been supplied by the investor, they now appear on the demand side, or as relational $\mathrm{O}$ factors. It is fair to term this a theoretical innovation, which, however, has not yet been modelled convincingly in the OLI framework.

From a business point of view, the ingenuity of relational $\mathrm{O}$ advantages lies in their being mixed OL. They are internal to a company, accessible and valuable assets engraved in an organization in a foreign nation. The acquisition of such $\mathrm{O}$ advantages may serve as the tool to change the $\mathrm{L}$ factor for the nation. Let us assume that a technologically advanced SE Asian firm wishes to expand its activities to the North American or EU marketplace on the basis of very limited market knowledge. The acquisition of a local company with the necessary knowledge about the local market might change -L into $+\mathrm{L}$, i.e., it might be the key to a profitable market entry.

On the one side, this may be seen as support for Rugman's, Itaki's and Casson's criticism of the paradigm: that $\mathrm{O}$ advantages are little more than the integration over time of a number of I advantages. However, this conceptual drawback is more than off-set by the fundamental gain obtained by the introduction of relational $\mathrm{O}$ advantages. The fundamental gain is the following: by acquiring $\mathrm{O}$ advantages beyond a border, a firm may change $-\mathrm{L}$ to $+\mathrm{L}$ and thus create the strategic perspective of its internationalization. The ensuing FDI is a decision 
outcome, not an automatic consequence of a given OLI configuration.

Thus the path-dependency of stages theories and the Uppsala model is broken. The leapfrogging, which has so often been noticed in empirical literature, has found an explanation based on rational choice. Instead of following the traditional - and slow - establishment chain towards FDIs, a number of possible strategic actions are considered, including such as may change the environment into an FDI-friendly one. This is made possible by precisely the O-L nature of acquired $\mathrm{O}$ advantages.

Dunning (1995) may have left us with a more complicated and less manageable theory, but its implication for practical business strategy is a very positive one. It may even prove useful for modern approaches to "business modelling” as it opens up for more deliberate choices between categories of strategic behaviour (see, e.g., Hamel 2000).

\section{CONCLUSION}

The main purpose of the present contribution is to supply traditional theories of internationalization with a variation on Dunning's theme, the OLI framework. On the assumption of the existence of (sufficient) O-advantages, the argument has been formulated on the basis of Iand L-advantages. The presence or absence of these determines the entry mode and form of operation in a foreign market.

A remaining issue is whether the pattern fits into figure 1, the Strandskov systematization. Decision making is supposed to be rational (economic), but drivers encompass internal 
(internalization) as well as external (location factors). In a sense, it combines the thinking of Williamson and Casson on the one hand and the analytical frame of Michael Porter on the other. As a general theory of internationalization, Dunning's framework appears to be based on internal and external rationality, and as such it represents something new in the matrix in table 1 . This view is further strengthened by the new focus on relational $\mathrm{O}$ advantages and its implications for strategic choice.

In a rough outline it may explain the market entry form by way of an internal and an external vector (I or L factors, respectively), and when the determinants change it is fully rational to change the operation form in a given market. A developing country that joins the WTO or enters into other binding agreements may provide an increase in I-advantages due to improved legal security, and thus shift from simple export to a sales subsidiary or from a joint venture to a wholly owned production facility.

It seems possible to equip this theoretical frame with some sort of operational measurements, and therefore with some predictability. However, unlike what is the case for stage models and the Uppsala model, this does not lead to theoretical determinism.

Dunning (1995) decided to put networks and strategic alliances under the OLI-umbrella in an attempt to explain what was now the tide in international business philosophy. This of course expanded the (intended) coverage of the OLI-framework, but at the same time it widened its focus beyond the individual firm. Networks or alliances simply indicate that, first, markets and hierarchies are substituted by the hybrid form, and, second, the functional areas of cooperation expand to sourcing, selling and the transfer of intellectual property. In table 3 this 
means a decrease in I-advantages, and an increase in L-advantages as partners ease access to foreign markets. The result is an upward drive to the right, i.e., cell (3). Tabel 4 is only a very initial attempt to closer assess what goes on in cell (3), which, over the past ten years, has caught much attention in business literature.

From a theoretical point of view, taking the network or alliance as the unit of analysis means that O-advantages have to be split up into those possessed exclusively by a firm and those that are shared with (some) members of the network. Shared knowledge, however, cannot be firm specific, which means that the OLI-framework will have to be worked out for each firm and for each network in which the firm engages. This amounts to an impossible analytical job, of which the proposed theory of OLI-internationalization relieves us. It may even be well suited to throw light on networks and their borders by means of the internalization dimension. There may be a trade-off between I- and L-advantages as decreased internalization undermines Ownership-specific advantages.

Remaining with the LI-framework leaves us with a leaner model that meets the five basic criteria listed in the introduction. The argumentation is rather transparent and not particularly complex. It may well be formulated in operational terms and subjected to falsification - and it may be provided with empirical content.

In sum, the LI framework is sufficient to make the eclectic paradigm a full-blown general theory of the internationalization of the firm and, in addition, the OL interaction enables the eclectic paradigm to provide helpful tools for developing a company’s international strategy. 


\section{REFERENCES}

Agarwal, J.P. (1980): Determinants of foreign direct investment: A Survey. Weltwirtschaftliches Archiv, 11/64.

Aharoni, Y. (1966): The foreign investment decision process. Boston

Andersen, O. (1993): On the internationalization process of firms: A critical analysis. Journal of International Business Studies, II/1993

Bartlett, A and S. Ghoshal (1989): Managing across borders. The transnational solution. Boston

Bilkey, W. J. and G. Tesar (1977): The export behavior of smaller Wisconsin manufacturing firms. Journal of International Business Studies, II/77, pp. 93-98

Buckley, P. and M. Casson (1976):The future of the multinational enterprise. London

Casson, M (1987): The firm and the market. Oxford

Casson, M (2000): Economics of international business. Cheltenham

Caves, R. E. (1971): International corporations. The industrial economics of foreign investment. Economica, Feb., pp 1-27

Cavusgil, S. T. (1980): On the internationalization process of firms. European Research, Nov. pp. 273-81

Czinkota, M. R. (1982): Export development strategies. US promotion policies. New York

Dunning, J. (1979): Explaining changing patterns of international production. Oxford Bulletin of Economics and Statistics, 41/4, pp. 269-95

Dunning, J. (1988): Explaining international production. London

Dunning. J (1993): Multinational enterprises and the global economy. Wokingham 
Dunning, J. (1995): Reappraising the eclectic paradigm in an age of alliance capitalism. Journal of International Business Studies, III/1995

Dunning, J. (1997): Alliance capitalism and global business. London

Dunning, J. and R. Narula (1996) (eds): Foreign direct investment and government: Catalysts for economic restructuring. London

Gatignon, H. and E. Anderson (1988): The MNCs degree of control over foreign subsidiaries. Journal of Law, Economics and Organization, 4, pp. 305-36

Harrigan, K. (1988): Joint ventures and competitive strategies. Strategic Management Journal, 2, pp. 395-412.

Hamel, G. (2000): Leading the Revolution. Harvard Business School Press.

Hedlund, G. (1986): The hypermodern MNC - a heterarchy? Human Resource Management, 25, pp. 9-35.

Håkansson, H (1987) (Ed): Industrial Technological Development. London

Itaki, M (1991): A critical assessment of the eclectic theory of the multinational enterprise. Journal of International Business Studies, II/1991

Johanson, J. and J. Vahlne (1977): The internationalization process of the firm. Journal of International Business Studies, 8, pjp. 23-32

Johanson, J. and F. Wiedersheim-Paul (1975): The internationalization of the firm: Four Swedish cases. Journal of Management Studies, Oct. pp 305-22

Johanson, J. and L-G Mattson (1984): Internationalization in industrial systems - a network approach. Stockholm

Kuhn, T. S. (1976): The Structure of Scientific Revolutions. 2. ed., University of Chicago Press.

Nohria, N. and S. Ghoshal (1997): The differentiated network 
Pfeffer, J. (1987): Bringing the environment back in. In: (ed) D. Teece: A resource dependence perspective. New York.

Pfeffer, J. and G. Salancik (1978): The external control of organizations. A resource dependency perspective. New York

Porter, M. (1980): Competitive strategy. New York

Porter, M. (1985): Competitive advantage. New York

Porter, M. (1986): Competition in global industries. New York

Porter, M. (1990): The competitiveness of nations. London and New York

Porter, M. (1991): Towards a dynamic theory of strategy. Strategic Management Journal, 12, pp. 95-117

Rugman, A. (1981): Inside the multinationals. The economics of internal markets. London

Stehn, J. (1992): Ausländische Direktinvestitionen in Industrieländern. Tübingen

Strandskov, J. (1995): Internationalisering af virksomheder. København

Strandskov, J. and K. Pedersen (2000): Pioneering FDI into the danish bacon industrry. Scandinavian Economic History Review, 3/2000, pp 42-56

Vernon, R (1966): International investment and international trade in the product cycle.

Quarterly Journal of Economics (May), pp. 190-207

Vernon, R. (1971): Sovereignty at Bay. The multinational spread of U.S. enterprises. New York

Williamson, O. (1975): Hierarchies and markets. New York

Williamson, O. (1985): The economic institutions of capitalism. New York

Yip, G. (1992): Total Global Strategy.

Yip, G. (1995): Global strategy ... in a world of nations? Reading 1.2 in R. Buzzell, J. Quelch and C. Bartlett: Global marketing management, $3^{\text {rd }}$. ed. Wokingham 
Table 1. A classification of theories of internationalization

\begin{tabular}{|l|l|l|}
\hline Driver / Decision type & Rational decisions & Organic decisions \\
\hline Internal & A Micro-economic & A Learning perspective \\
E.g. Transaction Cost & E.g. The Uppsala model \\
& Theory & An inter-organisat. \\
\hline External & An Industry econ. & perspective \\
& perspective & E.g. Network theory \\
& E.g. Positioning Theory & \\
\hline
\end{tabular}

Source: Strandskov (1995) 
Table 2. Alternative routes of servicing markets.

\begin{tabular}{|l|l|l|l|}
\hline Route of servicing & O advantage? & I advantage ? & L advantage? \\
\hline FDI & yes & yes & yes \\
\hline Trade (Export) & yes & yes & no \\
\hline Contractual transfer & yes & no & no \\
\hline
\end{tabular}

Source: Dunning (1988), p. 28 
Table 3. Internationalization modes (O advantages assumed)

\begin{tabular}{|l|l|l|}
\hline & $-L$ & $+L$ \\
\hline$-I$ & (1) Simple export & (3) Contractual agreements \\
\hline$+I$ & (2) Sales subsidiary & $\begin{array}{l}\text { (4) Foreign Direct } \\
\text { Investment }\end{array}$ \\
\hline
\end{tabular}


Table 4. A classification of contractual modes

\begin{tabular}{|l|l|l|}
\hline & O: Strong upstream & O: Weak upstream \\
\hline O: Strong downstream & strategic alliance & franchising \\
\hline O: Weak downstream & licensing & not defined \\
\hline
\end{tabular}

